\title{
The Norse Myth of Odin - Digital Art Series on Thought and Memory
}

\author{
Seana McNamara \\ NASA Ames Research Center \\ http://SeanaMcNamara.com \\ Seana@jabberwocky.net
}

\section{INTRODUCTION}

In my series, Thought and Memory, I explore how the mind wanders, following mythic paths, identifying with the Hero's Journey, diving into murky worlds that haven't yet congealed into archetypes, and experiencing transformation.

Art-making has always shared with archeology the challenge of digging for meaning. But, whereas the archeologist digs deeper and deeper to unearth the past, digital art adds layer upon layer, projecting images and ideas into the future. Art-making, like myth, taps into the archetypes we all share, reliving mental journeys via story-telling. As I create individual images, they flow, one into another in a process of free association, each image reacting to the previous in a running animation of changes, telling a visual story.

In this visual presentation I explore how medium and message are entwined in my digital art series, inspired by the myth of Odin and his two ravens, Thought and Memory.
The myth of Odin is the story of an exchange and also in some sense the story of the artist's sacrifice. Odin climbs a hill to the ash tree, Yggdrasill, to drink from the water of the spring of wisdom. But to drink, he must first sacrifice his eye to the spring. Whether this is a fair trade depends on your point of view. When Odin lost his eye, he could no longer see physical depth, but he gained intuition and spiritual insight beyond objective reality.

Odin's ravens, Thought and Memory, spin in the sunlight, tumbling over and over with the wind. As I tried to crystallize sensation, creating images that flowed from one to another, each symbol and form repeating, changing in size and orientation, I found that I also wanted narrative, although not in the way that Bosch's The Temptations of St Anthony clearly depicts supernatural temptation. Instead, I wanted visual onomatopoeias that would echo my process of art making - cannibalizing old work to create new work, warping, layering, sketching, and erasing.

Digital art is a medium to translate thought and memory. 